\begin{tabular}{|c|c|c|}
\hline Beitr. Ent. & Berlin & ISSN 0005-805X \\
\hline $\mathbf{4 8}(1998) 2$ & S. 449-468 & 05.10 .1998 \\
\hline
\end{tabular}

\title{
Lectotype and neotype designations in Dodecastichus STIERLIN, 1861 and Otiorhynchus GERMAR, 1824
}

\author{
(Coleoptera: Curculionidae)
}

\author{
LUIGI MAGNANO
}

Summary

Lectotypes of the following species are designated: Dodecastichus heydeni STIERLIN, 1861; Otiorhynchus (Acunotus) lutosus STIERLIN, 1858; O. (Amosilnus) oberti FAUST, (1886); O. (Arammichnus) dobrutschae STIERLIN, 1882; O. (Aranihus) misellus STIERLIN, 1861; O. (Aranihus) riguus STIERLIN, 1883; O. (Choilisanus) affinis HoCHHUTH, 1847; O. (Choilisanus) caroli STIERLIN, 1893; O. (Choilisanus) caucasicus STIERLIN, 1872; O. (Choilisanus) schoenherri STIERLIN, 1877; O. (Choilisanus) viridisetosus STIERLIN, 1905; O. (Egydelenus) jaltensis FORMANEK, 1926; O. (Elechranus) banaticus STIERLIN, 1861; O. (Elechranus) chalceus STIERLIN, 1861; O. (Elechranus) roubali PENECKE, 1931; O. (Ergiferanus) mus STIERLIN, 1862; O. (Lolatismus) chaudoiri HoCHHUTH, 1851; O. (Lolatismus) depressus STIERLIN, 1875; O. (Melasemnus) brevipennis STIERLIN, 1892; O. (Melasemnus) crucirostris HocHHUTH, 1851; 0. (Meriplodus) laconicus KIRSCH, 1880; O. (Mitomiris) astutus (FAUST, 1886); O. (Mitomiris) laniger FAUST, 1887; O. (Namertanus) pseudomias HochHUTH, 1847; O. (Nihus) proximus STIERLIN, 1861; O. (Nubidanus) punctirostris STIERLIN, 1883; O. (Nubidanus) ruminalis FAUST, 1894; O. (Osmobodes) rutilipes HoCHHUTH, 1851; O. (Osmobodes) tenuimanus FAUSt, 1890; O. (Osmobodes) venalis FAUST, 1888; O. (Otiomimus) desbrochersi STIERLIN, 1883; O. (Otiorhynchus) amabilis STIERLIN, 1861; O. (Otiorhynchus) auropupillatus STIERLIN, 1861; O. (Otiorhynchus) delatus FAUST, 1899; O. (Otiorhynchus) latissimus STIERLIN, 1861; O. (Otiorhynchus) scaberrimus STIERLIN, 1861; O. (Otiorhynchus) steppensis FAUST, 1888; O. (Otismotilus) auroguttatus STIERLIN, 1879; O. (Paracryphiphorus) nuncius FAUST, 1890; O. (Petalorrhynchus) crinitarsis STIERLIN, 1861; O. (Phalantorrhynchus) patruelis STIERLIN, 1861; O. (Phalantorrhynchus) planidorsis STIERLIN, 1886; O. (Pliadonus) schneideri STIERLIN, 1876; O. (Tournieria) siewersi FAUST, 1888; O. (Podonebistus) alaianus STIERLIN, 1886; O. (Podonebistus) bleusei FAUST, 1899; O. (Podonebistus) cylindricus STIERLIN, 1877; O. (Podonebistus) nefandus FAUST, 1888; O. (Podonebistus) prostratus HEYDEN, 1886; O. (Podonebistus) subparallelus STIERLIN, 1893; O. (Prototis) popovi FAUST, 1888; O. (Provadilus) carbonarius HoCHHUTH, 1847; O. (Pseudocryphiphorus) argillosus HосHнUTH, 1851; O. (Pseudocryphiphorus) irritabilis (FAUST, 1886); O. (Pseudocryphiphorus) zebei STIERLIN, 1861; O. (Rimenostolus) auripes STIERLIN, 1875; O. (Rusnepranus) arenosus STIERLIN, 1861; O. (Rusnepranus) heerii STIERLIN, 1858; O. (Stupamacus) erroneus (FAUST, 1886); O. (Stupamacus) infensus FAUST, 1888; O. (Stupamacus) pilosulus PENECKE, 1928; O. (Tournieria) cornicinus STIERLIN, 1861; O. (Tournieria) emgei STIERLIN, 1887; O. (Tournieria) lubriculus FAust, 1890; O. (Udonedus) koenigi FAUST, 1888; O. (Urorrhynchus) truncatus STIERLIN, 1861; O. (Zariedus) hystericus FAUST, 1892; O. (Zariedus) sedulus FAUST, 1894. Neotypes are designated for O. (Amosilnus) pityophilus GISTEL, 1857 and of $O$. (Postaremus) gelidus GISTEL, 1857. The following new synonymies (synonyms in square brackets) are established: $O$. velutinus GERMAR, $1824[=0$. desbrochersi STIERLIN, 1896 (not O. desbrochersi STIERLIN, 1883)]; O. laconicus KIRSCH, 1880 [= O. oertzeni STIERLIN, 1883]; O. nodo- 
sus (O. F. MÜLleR, 1754) [= O. gelidus GISTEL, 1857]; O. lavandus GERMAR, 1824 [= O. pityophilus GISTEL, 1857]; O. proximus STIERLIN, 1861 [ $=O$. depilis SMRECZYNSKI, 1959]; O. parvicollis GYLlENHAL, 1834 [ $=$ O. riguus STIERLIN, 1883]; O. caucasicus STIERLIN, 1872 [= O. viridisetosus STIERLIN, 1905]. Otiorhynchus erroneus (FAUST, 1886) is attributed species rank. Otiorhynchus affinis HOCHHUTH is removed from the synonymy with $O$. incivilis FALDERMANN, 1838; $O$. auroguttatus STIERLIN is removed from the synonymy of $O$. heerii STIERLIN, 1858 and transferred from $O$. (Rusnepranus) REITTER, 1912 to $O$. (Otismotilus) REITTER, 1912. New combinations are: Otiorhynchus (Rimenostolus) auripes STIERLIN from $O$. (Panorosemus) REITTER, 1913; O. (Rusnepranus) heerii STIERLIN from $O$. (Otismotilus) ReITTER, 1912; O. (Stupamacus) infensus FAUST from O. (Microphalantus) REITTER, 1912; O. (Elechranus) roubali PENECKE from O. (Cryphiphorus) STIERLIN, 1883; O. (Pliadonus) siewersi FAUST, 1888 from O. (Melasemnus) REITTER, 1912; O. (Podonebistus) alaianus STIERLIN, O. (Cryphiphorus) argillosus HochHUTH, O. (Lolatismus) depressus STIERLIN, O. (Ergiferanus) mus STIERLIN, O. (Podonebistus) prostratus HEYDEN, O. (Pliadonus) schneideri STIERLIN, and O. (Osmobodes) venalis FAUST, all thus far listed as species incertae sedis.

\section{Zusammenfassung}

Die Lectotypen der folgenden Arten wurden festgelegt: Dodecastichus heydeni STIERLIN, 1861; Otiorhynchus (Acunotus) lutosus STIERLIN, 1858; O. (Amosilnus) oberti FAUST, (1886); O. (Arammichnus) dobrutschae STIERLIN, 1882; O. (Aranihus) misellus STIERLIN, 1861; O. (Aranihus) riguus STIERLIN, 1883; O. (Choilisanus) affinis HochHUTH, 1847; O. (Choilisanus) caroli STIERLIN, 1893; O. (Choilisanus) caucasicus STIERLIN, 1872; O. (Choilisanus) schoenherri STIERLIN, 1877; O. (Choilisanus) viridisetosus STIERLIN, 1905; O. (Egydelenus) jaltensis FORMANEK, 1926; O. (Elechranus) banaticus STIERLIN, 1861; O. (Elechranus) chalceus STIERLIN, 1861; O. (Elechranus) roubali PENECKE, 1931; O. (Ergiferanus) mus STIERLIN, 1862; O. (Lolatismus) chaudoiri HochHUTH, 1851; O. (Lolatismus) depressus STIERLIN, 1875; O. (Melasemnus) brevipennis STIERLIN, 1892; O. (Melasemnus) crucirostris HochHUTH, 1851; 0. (Meriplodus) laconicus KIRSCH, 1880; O. (Mitomiris) astutus (FAUST, 1886); O. (Mitomiris) laniger FAUST, 1887; O. (Namertanus) pseudomias HochHUTH, 1847; O. (Nihus) proximus STIERLIN, 1861; O. (Nubidanus) punctirostris STIERLIN, 1883; O. (Nubidanus) ruminalis FAUST, 1894; O. (Osmobodes) rutilipes HoCHHUTH, 1851; O. (Osmobodes) tenuimanus FAUSt, 1890; O. (Osmobodes) venalis FAUST, 1888; O. (Otiomimus) desbrochersi STIERLIN, 1883; O. (Otiorhynchus) amabilis STIERLIN, 1861; O. (Otiorhynchus) auropupillatus STIERLIN, 1861; O. (Otiorhynchus) delatus FAUST, 1899; O. (Otiorhynchus) latissimus STIERLIN, 1861; O. (Otiorhynchus) scaberrimus STIERLIN, 1861; O. (Otiorhynchus) steppensis FAUST, 1888; O. (Otismotilus) auroguttatus STIERLIN, 1879; O. (Paracryphiphorus) nuncius FAUST, 1890; O. (Petalorrhynchus) crinitarsis STIERLIN, 1861; O. (Phalantorrhynchus) patruelis STIERLIN, 1861; $O$. (Phalantorrhynchus) planidorsis STIERLIN, 1886; O. (Pliadonus) schneideri STIERLIN, 1876; O. (Tournieria) siewersi FAUST, 1888; O. (Podonebistus) alaianus STIERLIN, 1886; O. (Podonebistus) bleusei FAUST, 1899; O. (Podonebistus) cylindricus STIERLIN, 1877; O. (Podonebistus) nefandus FAUST, 1888; O. (Podonebistus) prostratus HEYDEN, 1886; O. (Podonebistus) subparallelus STIERLIN, 1893; O. (Prototis) popovi FAUST, 1888; O. (Provadilus) carbonarius HochнUTH, 1847; O. (Pseudocryphiphorus) argillosus HochнUTH, 1851; O. (Pseudocryphiphorus) irritabilis (FAUST, 1886); O. (Pseudocryphiphorus) zebei STIERLIN, 1861; O. (Rimenostolus) auripes STIERLIN, 1875; O. (Rusnepranus) arenosus STIERLIN, 1861; O. (Rusnepranus) heerii STIERLIN, 1858; O. (Stupamacus) erroneus (FAUST, 1886); O. (Stupamacus) infensus FAUST, 1888; O. (Stupamacus) pilosulus PENECKE, 1928; O. (Tournieria) cornicinus STIERLIN, 1861; O. (Tournieria) emgei STIERLIN, 1887; O. (Tournieria) lubriculus FAUST, 1890; O. (Udonedus) koenigi FAUST, 1888; O. (Urorrhynchus) truncatus STIERLIN, 1861; O. (Zariedus) hystericus FAUST, 1892; O. (Zariedus) sedulus FAUST, 1894. Neotypen von O. (Amosilnus) pityophilus GISTEL, 1857 und von O. (Postaremus) gelidus GisTEL, 1857 wurden ausgewählt. Die folgenden neuen Synonyme (Synonyme in eckigen Klammern) wurden begründet: O. velutinus GERMAR, 1824 [ $=$ O. desbrochersi STIERLIN, 1896 (nicht $O$. desbrochersi STIERLIN, 1883)]; O. laconicus $\mathrm{KIRSCH}, 1880$ [ $=$ O. oertzeni STIERLIN, 1883]; O. nodosus (O. F. MÜLlER, 1754) [= O. gelidus GISTEL, 1857]; O. lavandus GERMAR, 1824 [= 0 . pityophilus GISTEL, 1857]; O. proximus STIERLIN, 1861 [ $=$ O. depilis SMRECZYNSKI, 1959]; O. parvicollis 
GyllenhAl, 1834 [ $=$ O. riguus STIERLIN, 1883]; O. caucasicus STIERLIN, 1872 [ $=$ O. viridisetosus STIERLIN, 1905]. Otiorhynchus erroneus (FAUST, 1886) erhielt einen neuen Status. Otiorhynchus affinis HochHUTH ist kein Synonym von $O$. incivilis FALDERMANN, 1838; O. auroguttatus STIERLIN ist kein Synonym von $O$. heerii STIERLIN, 1858 und ist zu übertragen aus $O$. (Rusnepranus) REITTER, 1912 in O. (Otismotilus) REITTER, 1912. Neue Kombinationen sind: Otiorhynchus (Rimenostolus) auripes STIERLIN aus O. (Panorosemus) REITTER, 1913; O. (Rusnepranus) heerii STIERLIN aus O. (Otismotilus) ReITTER, 1912; O. (Stupamacus) infensus FAUST aus $O$. (Microphalantus) REITTER, 1912; O. (Elechranus) roubali PENECKE aus $O$. (Cryphiphorus) STIERLIN, 1883; O. (Pliadonus) siewersi FAust, 1888 aus $O$. (Melasemnus) ReITTER, 1912; $O$. (Podonebistus) alaianus STIERLIN, O. (Cryphiphorus) argillosus HochHuTH, $O$. (Lolatismus) depressus STIERLIN, O. (Ergiferanus) mus STIERLIN, O. (Podonebistus) prostratus HeYDEN, $O$. (Pliadonus) schneideri STIERLIN, und $O$. (Osmobodes) venalis FAUST, alle diese sind als species incertae sedis aufgelisted.

Designation of lectotypes, paralectotypes and neotypes of the species is essential to unequivocally define names of them. This is particularly needed in the huge genus Otiorhynchus GERMAR, 1824, with some 1500 species and many forms described to date. The aim of this study is to fix the names of as many as possible Otiorhynchus taxa, for a checklist of all the species currently ascribed to this genus is in preparation. Results of the study of the types of Otiorhynchus species described by STIERLIN, HOCHHUTH (HOCHHUTH types, according to BEHNE (1991) have been purchased by STIERLIN), KRAATZ, FAUST, PENECKE, and FormaneK are here presented.

Printed red labels "Type", "Typus", "Syntypus" and "Holotypus" were often found in the checked collections: these designations, never published, have no value (ICZN 1989: art. 73 and recommendations $73 \mathrm{C}$ and $74 \mathrm{C}$ ).

All specimens of the STIERLIN collection bear a printed label "coll. Stierlin". Types of the FAUST collection bear a $0.5 \times 0.5 \mathrm{~mm}$ golden square label, and one "Samml. J. Faust, Ankauf 1900". All PeneCKE's specimens bear the label "Samml. K. A. Penecke, Geschenk 1940.20". These labels are no more reported below.

An oblique stroke indicates the separation between the labels, while commas separate different lines of a label. A partially printed red label has been attached to all selected lectotypes, paralectotypes and neotypes. Genera, subgenera and species are listed in alphabetical order. In the case of new combinations the species is reported in the subgenus in which it has been presently included.

The following acronym are used: DEI, Deutsches Entomologisches Institut, Eberswalde; SMTD, Staatliches Museum für Tierkunde, Dresden; ZSM, Zoologische Staatssammlung, München; NMP, Národní Museum v Praze, Prague.

\section{Aknowledgement}

I wish to thank the following persons who made available type material and who assisted me in various ways during the preparation of this paper: Dr. LOTHAR ZERCHE and Mr. LUTZ BEHNE, Deutsches Entomologisches Institut, Eberswalde; Dr. George Scherer and Dr. MARTIN BAEHR, Zoologische Staatssammlung, München; Dr. RÜDIGER KRAUSE, Staatliches Museum für Tierkunde, Dresden; Dr. JOSEF JELÍneK, Národní Museum v Praze, Prague.

A particular thanks to my friends Dr. ENZo ColonNelli of Rome for the revision of the manuscript and Dr. David Mifsud, University of Malta, Malta, for the revision of the English text. 


\section{Dodecastichus heydeni (STIERLIN, 1861) \\ Otiorhynchus heydeni STIERLIN, 1861:39}

Types (4) in DEI. Male lectotype (aedeagus dissected) labelled: Karst [handwritten] / Syntypus [red, printed] / Otiorrhynchus, (Dodecastichus), heydeni Stierl., det. P. Angelov, 1974 / Des. L. Magnano, 1995. Female paralectotype in Heyden collection labelled: Dalmatien [handwritten] / Heydeni mihi [handwritten] / Otiorrhynchus, (Dodecastichus), heydeni Stierl., det. P. Angelov, 1974 / Des. L. Magnano, 1995. Female paralectotype labelled: Karst [handwritten] / Syntypus [red, printed] / Otiorrhynchus, (Dodecastichus), heydeni Stierl., det P. Angelov, 1974 / Des. L. Magnano, 1995. Female paralectotype in coll. Heyden labelled: 126 / [violet, square label] / Heydeni female [handwritten] / lauri Dahl, Ragusa Dahl [handwritten] / Heydeni, Strl. Typ [handwritten] / Daniel vid. [handwritten] / Syntypus [red, printed] / Des. L. Magnano, 1995.

\section{Otiorhynchus (Acunotus) lutosus STIERLIN, 1858 Otiorhynchus lutosus STIERLIN, 1858:297}

Male lectotype in the Kraatz collection (DEI) labelled: Genéve, Stierlin [handwritten] / Coll. Kraatz / Syntypus [red, printed] / lutosus, Strl [handwritten / Des. L. Magnano, 1995.

Otiorhynchus (Amosilnus) oberti (FAUST, 1886)

Brachyrrhinus oberti (FAUST, 1886:153)

Types (3) in SMTD. Male lectotype: [golden square label] / Krasnojarsk, Obert [handwritten] / Type [red, printed] / Des. L. Magnano, 1995. Female paralectotypes (2 specimens on the same pin, glued to a single label]: [golden square label] / Krasnojarsk, Obert [handwritten] / Type [red, printed / Des. L. Magnano, 1995.

Remarks. Although O. oberti surely does not belong to the subgenus Amosilnus REITTER, 1913 because of its straight epipleura, I agree with ARNOLDI (1975) to provisionally leave this species in $O$. (Amosilnus) since it does not fit any of the thus far described subgenera.

Otiorhynchus (Amosilnus) pityophilus GISTEL, 1857; comb. nov. Otiorhynchus pityophilus GISTEL, 1857:18

Female neotype in ZSM collection labelled: "Austria / Neotypus / Otiorhynchus, pityophilus Gistel / Des. L. Magnano, 1995 / Otiorhynchus lavandus Germar / det. L. Magnano, 1995".

Remarks. GISTEL (1857) described in a valid way 820 new species of invertebrata. The paper was ignored until STRAND (1917) published a list of the animals described by GISTEL. Since the GISTEL collection does not exist (HORN et al. 1990), it became necessary to select a neotype to fix the name. The neotype has the granulate prothorax and the ash-coloured elytra mentioned by GISTEL (1857:18). The species belongs to O. (Amosilnus) (comb. nov.). It is also necessary to establish the new synonymy: Otiorhynchus lavandus GERMAR, 1824 (= Otiorhynchus pityophilus GisTel, 1857, syn. nov.).

\section{Otiorhynchus (Arammichnus) dobrutschae STIERLIN, 1882} Otiorhynchus dobrutschae STIERLIN, 1882:250

Female lectotype in Stierlin collection (DEI) labelled: Dobrutscha [handwritten] / Syntypus [red, printed] / Otiorhynchus, F. Zumpt det. 35, mandibularis [partially handwritten by Zumpt] / O. dobrutschae, Strl. [handwritten] / dobrutschae Strl, = mandibularis, Redtb., det. L. Magnano 1992 / Des. L. Magnano, 1995. 
Otiorhynchus (Aranihus) misellus STIERLIN, 1861

Otiorhynchus misellus STIERLIN, 1861:139

Male lectotype in DEI labelled: France merid [handwritten] / Coll. Dejean, Coll. Roelofs [handwritten] / rufipes Dej., [unpublished name by Dejean], Type [handwritten] / Syntypus [red, printed] / Alp. Gall [handwritten] / O. misellus, Strl. [handwritten] / Otiorhynchus, F. Zumpt det. 1935, misellus Strl. [handwritten by Zumpt] / Des. L. Magnano, 1995.

Otiorhynchus (Aranihus) riguus STIERLIN, 1883

Otiorhynchus riguus STIERLIN, 1883:456

Lectotype in DEI labelled: Canigou Pyren, [handwritten] / Otiorhynchus, F. Zumpt, 34, decorus Strl [handwritten] / O. ligneus var., riguus Frm. [handwritten] / Syntypus [red, printed] / Des. L. Magnano, 1995. O parvicollis Gyllenhal, 1834 (= O. riguus Stierlin, 1883), L. Magnano det. 1995.

Remarks. O. riguus STIERLIN was considered by HOFFMANN (1950) a "variety" of O. ligneus (Olivier, 1808). The study of the type made it evident that $O$. riguus STIERLIN, 1883 is a synonym of $O$. parvicollis GYLlENHAL, 1834 (syn. nov.).

Otiorhynchus (Choilisanus) affinis HOCHHUTH, 1847, stat. nov. Otiorhynchus affinis HocHHUTH, 1847:517

Female lectotype in DEI labelled: Caucasus [handwritten] / Syntypus [red, printed] / incivilis, Fal. [handwritten] / O. affinis Motsch., Hochh [handwritten]. Otiorhynchus affinis Hochhuth / Des. L. Magnano, 1995.

Remarks. O. affinis is a self-standing species, not a synonym of $O$. incivilis FALDERMANN, 1838:93 as indicated by REITTER, 1913 (stat. nov.). Elytral intervals of $O$. affinis are flat and wider than striae; its elytral pubescence is rather long and readily seen in side view, whereas intervals of $\boldsymbol{O}$. incivilis are granulate and convex, and elytral pubescence is shorter and difficult to see even in side view. Note that $O$. incivilis was described by SCHÖNHERR (in FALDERMANN, 1838), not by FALDERMANN as wrongly reported by subsequent authors.

Otiorhynchus (Choilisanus) caroli STIERLIN, 1893

Otiorhynchus caroli STIERLIN, 1893:408

Types (4) in DEI. Lectotype labelled: Abchasien, Rost [handwritten] / 7 / Syntypus [red, printed] / Des. L. Magnano, 1996. Paralectotype: Abchasien, Rost [handwritten] / Abchasien [handwritten] / Syntypus [red, printed] / O. caroli Stl.. / Des. L. Magnano, 1996. Two paralectotypes: caroli Stl, Abchasia, Rost [handwritten] / Syntypus [red, printed] / Coll. L. v. Heyden, DEI Eberswalde / Des. L. Magnano, 1996.

Otiorhynchus (Choilisanus) caucasicus STIERLIN, 1872

Otiorhynchus caucasicus STIERLIN, 1872:321

Types (5) in DEI. Female lectotype labelled: Kaukasus, Leder, 118 [printed] / Syntypus [red, printed] / Des. L. Magnano, 1996. Female paralectotype: Kaukasus, Leder, 118 [printed] / Reitter det. / Syntypus [red, printed] / O. caucasicus, Stierl / Des. L. Magnano, 1996. Male paralectotype: Kaukasus, Leder, 118 [printed] / caucasicus [printed] / Syntypus [red, printed] / DEI Eberswalde / Des. L. Magnano, 1996. Female paralectotype: Kaukasus, Leder [printed] / 
118 [printed] / Syntypus [red, printed] / coll. L. v. Heyden, DEI Eberswalde / Des. L. Magnano, 1996. Male paralectotype: Kaukasus, Leder [printed] / 118 [printed] / Syntypus [red, printed] / coll. L. v. Heyden, DEI Eberswalde / Des. L. Magnano, 1996.

Otiorhynchus (Choilisanus) schoenherri STIERLIN, 1877

Otiorhynchus (Tournieria) schoenherri STIERLIN, 1877:180

Male lectotype in DEI labelled: Caucasus [handwritten] / Syntypus [red, printed] / O. caucasicus, v. Schönherri Stl [handwritten] / Des. L. Magnano, 1996.

Remarks. O. schoenherri is a synonym of $O$. caucasicus STIERLIN, 1872 as stated by REITTER (1913).

Otiorhynchus (Choilisanus) viridisetosus STIERLIN, 1905

Otiorhynchus viridisetosus STIERLIN, 1905:56

Male lectotype in DEI labelled: Caucasus, Lornis M.te, 2000, E. König [printed] / Holotypus [red, printed] / O. viridisetosus, Sierlin / Des. L. Magnano, 1996.

Remarks. Study of the type revealed the new synonymy: O. caucasicus STIERLIN, 1872 (=O. viridisetosus STIERLIN, 1905, syn. nov.).

Otiorhynchus (Egydelenus) jaltensis FORMANEK, 1926

Otiorrhynchus jaltensis FORMANEK, 1926:145

Male lectotype and 2 females paralectotypes in the Formanek collection (NMP) labelled: Jalta 1910, Kulzer [handwritten] / Typus [red, printed] / Formanek [violet] jaltensis, Type [handwritten] / Des. L. Magnano, 1995.

Otiorhynchus (Elechranus) banaticus STIERLIN, 1861

Otiorhynchus banaticus STIERLIN, 1861:121

Types (2) in the Stierlin collection (DEI). Male lectotype labelled: Hungar., Frivald. [handwritten] / Coll. Kraatz / Syntypus [red, printed] / banaticus, Strl. [handwritten] / Des. L. Magnano, 1995. Female paralectotype: Ungarn [handwritten] / Syntypus [red, printed] / O. banaticus, Stl. [handwritten]. Otiorhynchus banaticus Stierlin / Des. L. Magnano, 1995.

Otiorhynchus (Elechranus) chalceus STIERLIN, 1861

Otiorhynchus chalceus STIERLIN, 1861:127

Types (3) in the Stierlin collection (DEI). Female lectotype labelled: Krain [handwritten] / Syntypus [red, printed] / O. chalceus, Stierlin [handwritten] / Des. L. Magnano, 1995. Male paralectotype and female paralectotype: Krain [handwritten] / Syntypus [red, printed] / Des. L. Magnano, 1995.

Otiorhynchus (Elechranus) roubali PENECKE, 1931, comb. nov. Otiorhynchus (Cryphiphorus) roubali PENECKE, 1931:120

Types (4) in SMTD. Male lectotype labelled: Slovakei, Gemar Silica [printed] / Otiorhynchus Roubali m. male, Penecke det. [partly printed] / Typus [red, printed] / Des. L. Magnano, 1996, Otiorhynchus (Elechranus) roubali Penecke, det. L. Magnano, 1996. Three females paralecto- 
types: Slovakei, Gemar Silica [printed] / Otiorhynchus Roubali m., Penecke det. / Typus [red, printed] / Des. L. Magnano, 1996, Otiorhynchus (Elechranus) roubali Penecke, det. L. Magnano, 1996.

Remarks. O. roubali is here transferred from O. (Criphiphorus) STIERLIN, 1861 to $O$. (Elechranus) REITTER, 1912 (comb. nov.).

Otiorhynchus (Ergiferanus) mus STIERLIN, 1862, comb. nov. Otiorhynchus mus STIERLIN, 1862:366

Female lectotype in Kraatz collection (DEI) labelled: [rot square label] / 87 / Syntypus [red, printed] / mus Stierlin, n. sp. nigripes Megerle, [handwritten] [unpublished name by Megerle] / Des. L. Magnano, 1995.

Remarks. O. mus is presently transferred from the species incertae sedis to O. (Ergiferanus) REITTER, 1912 (comb. nov.).

Otiorhynchus (Lolatismus) chaudoiri HOCHHUTH, 1851

Otiorhynchus chaudoiri НосHнUTH, 1851:77

Types (2) in DEI. female lectotype labelled: chaudoiri, Hochh. Typ., Caucas., Stierlin [handwritten] / Syntypus [red, printed] / Coll. L. v. Heyden, DEI Eberswalde / Des. L. Magnano, 1996. Female paralectotype: O. chaudoiri, Hochh, Hochh / Des. L. Magnano, 1996.

Remarks. The female paralectotype has not a locality label; its right antenna and left funiculus are missing.

Otiorhynchus (Lolatismus) depressus STIERLIN, 1875, comb. nov.

Otiorhynchus depressus STIERLIN, 1875:418

Type in the Stierlin collection (DEI) labelled: ?Caucas., Haberh. [handwritten] / depressus m., n. sp. [handwritten] / Holotypus [red, printed]. Lectotypus / Des. L. Magnano, 1995.

Remarks. The type locality (?Caucas.) of $O$. depressus (described in the Deutsche Entomolologische Zeitschrift and not in the Berliner Entomologische Zeitschrift as wrongly cited by LONA (1936:221) is uncertain. The species was reported with a question mark from Turkey by STIERLIN (1883:417), and from Italy and Caucasus by REITTER (1914:119) also with a question mark. The study of the type allows $O$. depressus to be transferred from the species incertae sedis to O. (Lolatismus) REITTER, 1912 (comb. nov.).

Otiorhynchus (Melasemnus) brevipennis STIERLIN, 1892

Otiorhynchus (Tournieria) brevipennis STIERLIN, 1892:359

Female lectotype in DEI labelled: Creta [handwritten] / Syntypus [red, printed] / O. brevipennis Stl. / Des. L. Magnano, 1995.

Otiorhynchus (Melasemnus) crucirostris HоCHнUTH, 1851

Otiorhynchus crucirostris HосHнUTH, 1851:67

Lectotype in the Stierlin collection (DEI), labelled: Caucasus [handwritten] / Coll. Stierlin / Syntypus [red, printed] / O. ovalipennis Schh., 1843 = crucirostris Hochh. [handwritten] / Des. L. Magnano, 1995. 
Remarks. The synonymy of this species with O. ovalipennis BOHEMAN, 1843, established by STIERLIN (1872) was confirmed by the examination of the type.

\section{Otiorhynchus (Meriplodus) laconicus KIRSCH, 1880}

Otiorhynchus laconicus KIRSCH, 1880:14

Types (6) in the Kirsch collection (SMTD). Female lectotype labelled: Taygetos, Kirsch [handwritten] / Typus [red, printed] / Des. L. Magnano, 1996. Five females paralectotypes: Taygetos, Kirsch [handwritten] / Typus [red, printed] / Des. L. Magnano, 1996.

Remarks. The study of the type series confirms the synonymy of $O$. oertzeni STIERLIN, 1883 with O. laconicus KIRSCH, 1880 (syn. nov.), already supposed but not formally proposed by F. SOLARI (1950). In the abundant material studied no males were found, so the species is most probably parthenogenetic. This may also justify the small morphological differences found in the two Greek populations from Mount Chelmos and Mount Taygetos studied.

Otiorhynchus (Mitomiris) astutus (FAUST, 1886)

Brachyrrhinus (Tournieria) astutus FAUST, 1886:155

Types (2) in the Faust collection (SMTD). Male lectotype labelled: [golden square label]; male Fl. Tamga, Akinin [handwritten] / Type [red, printed] / Des. L. Magnano, 1995. Female paralectotype: [golden square label] / Ak-baital., Kuschak. / Coll. J. Faust 1900 / Type [red, printed] / Des. L. Magnano 1995.

Remarks. Three specimens are in the FAUST collection under this name; however, only two belong to this species. The third specimen is an O. tardipes REITTER, 1912. The label borne by the male lectotype indicates the name of Akinin as the collector, which is not that of Balassoglo, as reported in the description (FAUST 1886).

\section{Otiorhynchus (Mitomiris) laniger FAUST, 1887}

Otiorhynchus laniger FAUST, 1887:294

Types (3) in SMND. Female lectotype labelled: [golden square label] / Turkestan, Conradt [handwritten] / Type [red, printed] / Des. L. Magnano, 1996. Two female lectotypes (in the same pin, the under one glued on back side) [golden square label] / Turkestan, Conradt [handwritten] / Type [red, printed] / Des. L. Magnano, 1996.

Remarks. The middle leg of the lectotype is lacking. The firstly mentioned paralectotype lacks antennal joints 4 to 7 , club, and tarsus of the right fore leg. The other paralectotype lacks antennal joints 5-7 and club.

Otiorhynchus (Namertanus) pseudomias HocHнUTH, 1847

Otiorhynchus pseudomias HocHHUTH, 1847:524

Male lectotype in DEI labelled: Caucasus [handwritten] / Type [white, printed / Syntypus [red, printed] / O. pseudomias Hh, = lutosus Stierl / Des. L. Magnano, 1996.

Remarks. The study of the type confirmed the synonymy reported on one of the labels borne by the specimen. 
Otiorhynchus (Nihus) proximus STIERLIN, 1861

Otiorhynchus proximus STIERLIN, 1861:163

Types (2) in the Stierlin collection (DEI). Male lectotype labelled: Siebenburgen [handwritten] / O. proximus, Stierlin [handwritten] / Syntypus [red, printed] / Otiorrhynchus, depilis Smrecz., Smreczynski det. 1956 [handwritten by Smreczynski] / Des. L. Magnano, 1995. Female paralectotype: Transsylv., Hampe [handwritten] / Coll. Kraatz / proximus. Stierlin [handwritten] / Syntypus [red, printed] / Otiorrhynchus, depilis Smrecz., Smreczynski det. 1956 [handwritten by Smreczynski] / Des. L. Magnano, 1995.

Remarks. The two specimens have been renamed (and consequently labelled) by SMRECZYNSKI in 1956 "O. depilis Smreczynski det. 1956" because in his opinion they do not agree with STIERLIN's original description. Being, however, SMRECZYNSKI's considerations wrong, is here established the new synonymy: O. proximus STIERLIN, 1861 (= O. depilis SMRECZYNSKI, 1959, syn. nov.).

Otiorhynchus (Nubidanus) punctirostris STIERLIN, 1883

Otiorhynchus (Arammichnus) punctirostris STIERLIN, 1883:548

Female lectotype in DEI labelled: Caucasus [handwritten] / Holotypus [red, printed] / O. punctirostris, Stl. / Des. L. Magnano, 1996.

Remarks. The left antenna of the lectotype, the middle right leg, the third tarsus and onychium of the middle left leg, the onychium of fore and hind legs are lacking.

Otiorhynchus (Nubidanus) ruminalis FAUST, 1894

Otiorhynchus ruminalis FAUST, 1894:53

Female lectotype in SMND labelled: [golden square label] / Kopet, Dagh [handwritten] / rumina, lis Fst. [handwritten] / Type [red, printed] / Des. L. Magnano, 1996.

Otiorhynchus (Osmobodes) rutilipes HOCHHUTH, 1851

Otiorhynchus rutilipes HocHHUTH, 1851:75

Female lectotype in DEI labelled: Sibiria [handwritten] / O rutilipes, Hochh. Hochh. / Syntypus [red, printed] / Des. L. Magnano, 1996.

Remarks. The species is a synonym of $O$. cribrosicollis BOHEMAN, 1843, as indicated by REITTER (1912).

Otiorhynchus (Osmobodes) tenuimanus FAUST, 1890

Otiorhynchus tenuimanus FAUST, 1890:13

Types (3) in SMTD. Male lectotype labelled: [golden square label] / Osnatjen.[naja], Hamarstr. [öm] [handwritten] / tenuimanus, Fst [handwritten] / Type [red, printed] / Des. L. Magnano, 1995. Female paralectotype: [golden square label] / Osnatjen.[naja], Hamarstr.[öm] [handwritten] / tenuimanus [handwritten] / Type [red, printed] / Des. L. Magnano, 1995. Female paralectotype: [golden square label] / Osnatjen.[naja], Hamarstr.[öm] [handwritten] / tenuima, nus [handwritten] / Type [red, printed] / Des. L. Magnano, 1995.

Remarks. The male lectotype and the first mentioned female paralectotype are mounted on the same pin. The other paralectotype is much damaged, with the fore and left middle legs missing. 
Otiorhynchus (Osmobodes) venalis FAUST, 1888, comb. nov. Otiorhynchus venalis FAUST, 1888:153

Types (3) in SMTD. Male lectotype labelled: [golden square label] / Dauria, Sahlberg [handwritten] / venalis, Faust [handwritten] / Type [red, printed] / Des. L. Magnano, 1995. Two females paralectotypes: [golden square label] / Dauria, Sahlberg [handwritten] / venalis, Faust [handwritten] / Type [red, printed] / Des. L. Magnano, 1995.

Remarks. $O$. venalis is presently moved from the species incertae sedis to $O$. (Osmobodes) REITTER, 1912 (comb. nov.). Another female specimen with the locality label "Siberia" is in the FAUST collection.

\section{Otiorhynchus (Otiomimus) desbrochersi Stierlin, 1883 \\ Otiorhynchus desbrochersi Stierlin, 1883:457}

Types (5) in DEI. Male lectotype (aedeagus dissected) labelled: Griechenland [handwritten] / Otiorhynchus, F. Zumpt det. 1936, desbrochersi Strl. / Des. L. Magnano, 1995. Female paralectotype: Attica [handwritten] / 5 [white square label] / $87 \mathrm{Db}$. [white square label] / O. carcelli var. desbrochersi Strl [handwritten] / Otiorhynchus, F. Zumpt det. 1936, desbrochersi Strl. / Des. L. Magnano, 1995. Female paralectotype: Peloponnesus [handwritten] / Dr. Daniel det. / Ot carceli Gyll. / Otiorhynchus, F. Zumpt det. 1936, desbrochersi Strl. / Des. L. Magnano, 1995. Female paralectotype: Attica [handwritten] / desbrochersi [handwritten] / Dr. Daniel det. / O. Leonhard / Ot carceli var. desbrochersi Strl / Otiorhynchus, F. Zumpt det. 1936, desbrochersi Strl. / Des. L. Magnano, 1995. Male paralectotype: Beotia [handwritten] / Otiorhynchus, F. Zumpt det. 1936, desbrochersi Strl. / Des. L. Magnano, 1995.

Remarks. The species was described with only two lines as a "var." of $O$. carceli by STIERLIN (1883): no locality nor type material was indicated. ZUMPT raised later (1936) this "var." to specific level, comparing $O$. desbrochersi with $O$. carceli, a very closely related species. In the STIERLIN collection there are five specimens, all studied by ZUMPT in 1936. A male specimen with the aedeagus dissected is designated as the lectotype.

The specific name Otiorhynchus desbrochersi was firstly used by in 1883 for the present species, and later also used (STIERLIN 1896:44) for a species from the Carpathians. Reading the original description, it is evident that this latter species must be synonymized with $O$. velutinus GERMAR, 1824 (syn. nov.). Note that in the STIERLIN collection under this second name there is a label indicating that the specimen(s) were moved to Trachyphloeus GERMAR, 1917: this indication, however, evidently refers to $T$. desbrochersi STIERLIN, 1885 and not to O. desbrochersi STIERLIN, 1896, also because the description of the latter cannot be referred to a Trachyphloeus. It appears thus probable that the type(s) of $O$. desbrochersi STIERLIN, 1896 have been lost.

\section{Otiorhynchus (Otiorhynchus) amabilis STIERLIN, 1861}

Otiorhynchus amabilis STIERLIN, 1861:85

Types (2) in DEI. Female lectotype labelled: female [black square label] / Piemont [handwritten] / Reitter det. / = amplipennis [handwritten] / Syntypus [red, printed] / amabilis, m [handwritten] / Des. L. Magnano, 1995. Male paralectotype: Piemont [handwritten] / Syntypus [red, printed] / Des. L. Magnano, 1995.

Remarks. Check of the type material confirmed the synonymy of $O$. amabilis with $O$. amplipennis FAIRMAIRE, 1859 already proposed by REITTER (1912) but later brought into question by LONA (1936). 


\section{Otiorhynchus (Otiorhynchus) auropupillatus STIERLIN, 1861}

Otiorhynchus auropupillatus STIERLIN, 1861:47

Types (2) in DEI. Male lectotype labelled: [violet square label] / Italien [handwritten] / Syntypus [red, printed] / O. auropupil, latus Stl. [handwritten] / Otiorhynchus, auropupillatus male, Strl., vid. L. Magnano '68 [partially handwritten] / Des. L. Magnano, 1995. Female paralectotype: Italia [handwritten] / 17 [square] / Coll. Kraatz / auropupillatus, Stierl. [handwritten] / Syntypus [red, printed] / Otiorhynchus, auropupillatus female, Strl., vid. L. Magnano '68 / Des. L. Magnano, 1995.

\section{Otiorhynchus (Otiorhynchus) delatus FAUST, 1899 \\ Otiorhynchus delatus FAUST, 1899:4}

Female lectotype in SMTD labelled: [golden square label] / Madagascar, Sikora / deferlatus, Faust / Otiorhynchus, deferlatus, Fst. / Type [red, printed] / Des. L. Magnano, 1996.

Remarks. $O$. delatus, although similar to $O$. sanguinipes, is more closely related to $O$. niger (FABRICIUS, 1775) from which differs by the narrower rostrum with less expanded pterigia, upper side of pronotum less convex, sided of pronotum almost straigh, prothorax cone-like truncated forward, antenna shorter, strial pits denser. In the description FAUST (1899) questioned about the occurrence of an Otiorhynchus in Madagascar. The finding of a relative of $O$. niger in Madagascar is very unlikely, and I agree with FAUST's doubts.

\section{Otiorhynchus (Otiorhynchus) latissimus STIERLIN, 1861 \\ Otiorhynchus latissimus STIERLIN, 1861:79}

Male lectotype in the Stierlin collection (DEI) labelled: Banat [handwritten] / Syntypus [red, printed] / O. latissimus Stl. [handwritten] / Des. L. Magnano, 1995.

\section{Otiorhynchus (Otiorhynchus) scaberrimus STIERLIN, 1861 \\ Otiorhynchus scaberrimus STIERLIN, 1861:52}

Types (3) in the Stierlin collection (DEI). Male lectotype labelled: [square label] / Italia [handwritten] / coll. Kraatz / Dtsch. Ent. Inst. Eberswalde / Syntypus [red, printed] / Des. L. Magnano, 1995. Female paralectotype: Italia [handwritten] / Evans / S. / 5 / Coll. Kraatz / scaberrinus, Stierl. [handwritten] / Dtsch. Ent. Inst, Eberswalde / Otiorhynchus, scaberrimus Strl., det. L. Magnano '65 [partly handwritten] / Syntypus [red, printed] / Des. L. Magnano, 1995. Male paralectotype: Italien [handwritten] / Syntypus [red, printed] / Dtsch. Ent. Inst., Eberswalde / Otiorhynchus, scaberrimus male, Stierl., det. L. Magnano '65 [partly handwritten] / Des. L. Magnano, 1995.

\section{Otiorhynchus (Otiorhynchus) steppensis FAUST, 1888 \\ Otiorhynchus steppensis FAUST, 1888:147}

Types (4) in SMND. Male lectotype labelled: [golden square label] / Oremburg, Akinin [handwritten] / Type [red, printed] / Des. L. Magnano, 1995. Male paralectotype [golden square label] / male Orenburg, Eversmann [handwritten] / Type [red, printed] / Des. L. Magnano, 1995. Female paralectotype [golden square label] / Orenburg, Akinin [handwritten] / Type [red, printed] / Des. L. Magnano, 1995. Male paralectotype [golden square label] / male Samara, Faust [handwritten] / Type [red, printed] / Des. L. Magnano, 1995. 
Remarks. Tarsal joints 2 and 3 of the right hind leg of the lectotype are missing. One of the paralectotypes lacks the left hind leg. The type material confirms the synonymy of $O$. steppensis with $O$. concinnus GYLLENHAL, 1834, established by REITTER (1913).

Otiorhynchus (Otismotilus) auroguttatus STIERLIN, 1879, stat. nov. et comb. nov. Otiorhynchus auroguttatus STIERLIN, 1879:512

Male lectotype in DEI labelled: [golden square label] / Türkei [handwritten] / Holotypus [red, printed] / O. auroguttatus, Stl. [handwritten] / Des. L. Magnano, 1995.

Remarks. This species was synonymized by REITTER (1913) with O. heerii STIERLIN, 1858. The type material revealed not only its specific validity (stat. nov.), but also that $O$. auroguttatus must be moved from O. (Rusnepranus) ReITTER, 1912 to O. (Otismotilus) ReITTER, 1912 (comb. nov.).

\section{Otiorhynchus (Paracryphiphorus) nuncius FAUST, 1890}

Otiorhynchus (Cryphiphorus) nuncius FAUST, 1890:321

Types (3) in the Faust collection (SMTD). Male lectotype (aedeagus dissected) labelled: [golden square label] / Veluchi, [handwritten name by Faust] / nuncius, Faust [handwritten] / Paratypus, Cryphiphorus, nuncius, Faust [red, partly printed] / Otiorhynchus, nuncius Fst., lectotypus, W. Braun des. 1995 [white, partly printed] / Des. L. Magnano, 1996. One female and one male paralectotypes labelled: [golden square label] / Veluchi, [handwritten name by Faust] / nuncius, Faust [handwritten] / Paratypus, Otiorhynchus, nuncius, Faust [red, partly printed] / Otiorhynchus, nuncius Fst., paralectotype, W. Braun des. 1995 [white, partly printed] / Des. L. Magnano, 1996

Remarks. The lectotype was re-mounted on a label and the aedeagus was dissected by W. BRAUN. Paralectotypes are instead pierced by a pin. The unpublished lectotype designation by W. BRAUN is presently validated.

\section{Otiorhynchus (Petalorrhynchus) crinitarsis STIERLIN, 1861 Otiorhynchus crinitarsis STIERLIN, 1861:100}

Male lectotype in DEI labelled: Gall. mer. [handwritten] / Holotypus [red, printed] / Zumpt det. / cupreosparsus, F. Zumpt det. 1932, crinipes Strl. [partially handwritten] / O. crinitarsis Stierl. [handwritten] / Des. L. Magnano, 1995.

Remarks. Although LonA (1936), followed by HofFMANN (1950), raised O. crinitarsis to subspecific level, study of the type material confirmed the synonymy of $O$. crinitarsis with $O$. cupreosparsus (FAIRMAIRE, 1859) already proposed by REITTER (1913).

\section{Otiorhynchus (Phalantorrhynchus) patruelis STIERLIN, 1861}

Otiorhynchus patruelis STIERLIN, 1861:175

Types (2) in DEI. Male lectotype labelled: Algier [printed] / Syntypus [red, printed] / O. patruelis, Stierl. [handwritten] / Des. L. Magnano, 1995. Male paralectotype: 608, patruelis Strl., ?Alger. cantene, Strl. Typ. [handwritten] / coll. Heyden / Daniel, vid. [handwritten] / Syntypus [red, printed] / Des. L. Magnano, 1995. 
Otiorhynchus (Phalantorrhynchus) planidorsis STIERLIN, 1886

Otiorhynchus planidorsis STIERLIN, 1886:283

Male lectotype in DEI labelled: Gallia [handwritten] / Holotypus [red, printed] / O. planidorsis Stl. / Des. L. Magnano, 1996.

Remarks. The synonymy of $O$. planidorsis with Otiorhynchus moestus GyllENHAL, 1834, proposed by K. and J. DANIEL (1898) was found correct.

Otiorhynchus (Pliadonus) schneideri STIERLIN, 1876, comb. nov. Otiorhynchus (Tournieria) schneideri STIERLIN, 1876:501

Male lectotype in the Schneider collection (SMTD) labelled: [golden square label] / Typus [red, printed] / Zthra Zdaro. Mta, (9000') in Moos [handwritten] / Prof. Schneider, vermächt, 1903 / Des. L. Magnano, 1995.

Remarks. O. schneideri is here transferred from the species incertae sedis to $O$. (Pliadonus) REITTER, 1914 (comb. nov.).

Otiorhynchus (Pliadonus) siewersi FAUST, 1888, comb. nov. Otiorhynchus (Tournieria) siewersi FAUST, 1888:152

Types (3) in SMND. Male lectotype labelled: [golden square label] / Manglis, Siewers [handwritten] / Type [red, printed] / Des. L. Magnano, 1995. Two females paralectotypes in the same pin: [golden square label] / Manglis, Siewers [handwritten] / Type [red, printed] / Des. L. Magnano, 1995.

Remarks. The species is here transferred from O. (Melasemnus) REITTER, 1912 to $O$. (Pliadonus) REITTER, 1912 (comb. nov.).

Otiorhynchus (Podonebistus) alaianus STIERLIN, 1886, comb. nov. Otiorhynchus (Tournieria) alaianus STIERLIN, 1886:191

Male lectotype (aedeagus dissected) in the Stierlin collection (DEI) labelled: Alai, Turkest., Staudinger [handwritten] / Dan. vid. [handwritten] / Reitt., vid. [handwritten] / Syntypus [red, printed] / alaianus, Strl, unic. (unreadable) [handwritten] / Des. L. Magnano, 1995.

Remarks. O. alaianus is moved from the species incertae sedis to O. (Podonebistus) REITTER, 1912 (comb. nov.).

Otiorhynchus (Podonebistus) bleusei FAUST, 1899

Otiorhynchus bleusei FAUST, 1899:173

Male lectotype in the Faust collection (SMTD) labelled: [golden square label] / Rhodes, (Turquie d'Asie), L. Bleuse [printed] / bleusei Faust / Des. L. Magnano, 1995.

Remarks. In the FAUST collection there is only one specimen of the three quoted in the description (FAUST 1899). 
Otiorhynchus (Podonebistus) cylindricus STIERLIN, 1877

Otiorhynchus (Tournieria) cylindricus STIERLIN, 1877:177

Types (2) in DEI. Female lectotype labelled: Kaukasus, Leder / Syntypus [red, printed] / O. cylindricus, Stl [handwritten] / Des. L. Magnano, 1995. Female paralectotype: Kaukasus, Leder / Otiorhynchus, F. Zumpt det. 1932, cylindricus Strl. / Des. L. Magnano, 1995.

Remarks. $O$. cylindricus STIERLIN and its synonym $O$. subparallelus STIERLIN, have been transferred by ARNoLdi (1972) from $O$. (Choilisanus) ReITTER, 1913 to $O$. (Podonebistus) ReITTER, 1913. O. cylindricus has priority over $O$. subparallelus STIERLIN, 1893, the male type of which is labelled "Abchasien" (see below): they are simply the two sexes of the same species.

\section{Otiorhynchus (Podonebistus) nefandus FAUST, 1888}

Otiorhynchus nefandus FAUST, 1888:151

Types (4) in SMTD. Male lectotype labelled: [golden square label] / Tauria, Dohrn [handwritten] / Type [red, printed] / Des. L. Magnano, 1995. Male paralectotype: [golden square label] / Tauria, Dohrn [handwritten] / O. nefandus, Faust [handwritten] / Syntypus [red, printed] / Des. L. Magnano, 1995. Male and female paralectotypes mounted on the same pin (male above female): [golden square label] / Tauria, Dohrn [handwritten] / Typus [red, printed] / Des. L. Magnano, 1995.

Otiorhynchus (Podonebistus) prostratus HEYDEN, 1886, comb. nov. Otiorhynchus prostratus HEYDEN, 1886:280

Lectotype (?female) in DEI labelled: Narmangan, Turkest., Staudgr [handwritten] / tenuis, orig. Strl. / Daniel, vid. / Holotypus [red, printed] / Reitter, vid. / prostratus, Heyd., tenuis Strl., Stierlin hat, 3 x den Namen, verwendet, vide Ent. Nachr, 99:176 [handwritten] / Des. L. Magnano, 1995.

Remarks. The study of the type of $O$. prostratus allows it to be moved from the species incertae sedis to $O$. (Podonebistus) REITTER, 1912 (comb. nov.). The name O. tenuis have been used three times by STIERLIN: firstly in 1883 (STIERLIN 1883:98) for a species different from $O$. prostratus, also from Turkestan; another time (STIERLIN 1885:294) for the present species, whose name was changed in prostratus by HEYDEN (1886); and again (STIERLIN 1899) for another species which is a synonym of $O$. elegantulus GERMAR, 1824.

Otiorhynchus (Podonebistus) subparallelus STIERLIN, 1893

Otiorhynchus (Tournieria) subparallelus STIERLIN, 1893:409

Type in DEI. Male lectotype labelled: Abchasien, Rost [handwritten] / Holotypus [red, printed] / Des. L. Magnano, 1995.

Remarks. See the above remarks to O. cylindricus STIERLIN.

\section{Otiorhynchus (Postaremus) gelidus GISTEL, 1857 \\ Otiorhynchus gelidus GISTEL, 1857:18}

Female neotype in ZSM labelled Austria /Neotypus / Otiorhynchus, gelidus Gistel / Des. L. Magnano, 1995 / Otiorhynchus nodosus (O. Müller, 1754) / det. L. Magnano, 1995” 
Remarks. The female neotype of $O$. gelidus, here designated to fix the name since a GiSTEL' collection does not more exist (HoRN et. al., 1990) has the punctured striae, the black elytra, the spot of pubescence and the black antennae and legs mentioned in the vague original description (GISTEL, 1857). The following new synonymy is here established: Otiorhynchus nodosus (O. F. MÜLLER, 1754) (= Otiorhynchus gelidus GISTEL, 1857, syn. nov.).

\section{Otiorhynchus (Prototis) popovi FAUST, 1888}

Otiorhynchus (Arammichnus) popovi FAUST, 1888:154

Types (3) in SMTD. Male lectotype labelled: [golden square label] / Kjachta, Dohrn [handwritten] / popovi, Faust [handwritten] / Type [red, printed] / Des. L. Magnano, 1995. Two females paralectotypes: [golden square label] / Kjachta, Dohrn [handwritten] / popovi, Faust [handwritten] / Type [red, printed] / Des. L. Magnano, 1995.

\section{Otiorhynchus (Provadilus) carbonarius HoCHнUTH, 1847 \\ Otiorhynchus carbonarius HOCHHUTH, 1847:519}

Female types (2) in DEI. Lectotype labelled: Armenia [handwritten] / Syntypus [red, printed] / O. carbonarius, Hochh., DEI Eberswalde/ Des. L. Magnano, 1996. Paralectotype: Syntypus [red, printed] / DEI Eberswalde / Des. L. Magnano, 1996.

Remarks. Antennomeres 5-7 and club of left antenna, antennomeres 4-7 and club of right antenna, tarsi 2-3, onychium of right leg and onychium of left leg of the lectotype are lacking. Funiculus of left antenna, tarsi of left middle and hind right legs of the paralectotype are also lacking.

\section{Otiorhynchus (Pseudocryphiphorus) argillosus HocHHUTH, 1851 Otiorhynchus argillosus HOCHHUTH, 1851:73}

Female lectotype in DEI (re-mounted and glued on a label), labelled: Caucasus [handwritten] / O. argillosus, Hochh. / Historisches Exemplar [red, printed] / argillosus, Hochh. / Lectotypus Otiorhynchus argillosus Hochh, Des. Korotyaev 1990 / Des. L. Magnano, 1995.

Remarks. The right antenna and the middle and hind tibiae are lacking in the lectotype. $O$. argillosus was considered as a species incertae sedis but it must be included in $O$. (Pseudocryphiphorus) MAGNANO, in print (comb. nov.). The lectotype designation by KOROTYAEV was not published and consequently has no nomenclatorial value.

\section{Otiorhynchus (Pseudocryphiphorus) irritabilis (FAUST, 1886)}

Brachyrrhynus irritabilis FAUST, 1886:154

Types (2) in SMTD. Male lectotype labelled: [golden square label] / Minussinsk, Martianof [handwritten] / Paratypus [printed], Otiorrhynchus, irritabilis, Faust [red, partially handwritten] / Des. L. Magnano, 1995. Female paralectotype: [golden square label] / Krasnojarsk, Streblof [handwritten] / Type [red, printed], Otiorrhynchus, irritabilis, Faust / Des. L. Magnano, 1995.

Remarks. According to the original description (FAUST 1886) three specimens were used: a male and a female for the typical form, and a male for the "var.". The male labelled "Paratypus" has been selected as the lectotype because it comes from the type locality. The right antenna of the lectotype, the fore right leg and the tarsus of the middle right leg are lacking. 
Otiorhynchus (Pseudocryphiphorus) zebei STIERLIN, 1861

Otiorhynchus zebei STIERLIN, 1861:122

Lectotype in the Stierlin collection (DEI) labelled: Serbien [handwritten] / 200 / Coll. Kraatz / Zebei Stl [handwritten] / Syntypus [red, printed] / Des. L. Magnano, 1995.

Otiorhynchus (Rimenostolus) auripes STIERLIN, 1875, comb. nov. Otiorhynchus (Tournieria) auripes STIERLIN, 1875:335 (pro 431)

Types (4) in DEI. Male lectotype labelled: Persia [handwritten] / Syntypus [red, printed] / O. auripes Faust. / Des. L. Magnano, 1996. One male and two females paralectotypes: Schaku [printed] / Syntypus [red, printed] / Des. L. Magnano, 1996.

Remarks. Left and the middle legs of the lectotype are lacking. Male paralectotype is lacking of the distal third of the right fore tibia. A female paralectotype lacks the left middle leg. The study of the types of $O$. auripes allows it to be transferred from $O$. (Panorosemus) ReITTER, 1912 to O. (Rimenostolus) REITTER, 1912 (comb. nov.).

\section{Otiorhynchus (Rusnepranus) arenosus STIERLIN, 1861 \\ Otiorhynchus arenosus STIERLIN, 1861:139}

Type in the Stierlin collection (DEI) labelled: male lectotype: Italien [handwritten] / Syntypus [red, printed] / O. arenosus, Stierlin [handwritten] / Des. L. Magnano, 1995.

Otiorhynchus (Rusnepranus) heerii STIERLIN, 1858, comb. nov. Otiorhynchus heerii STIERLIN, 1858:289

Female lectotype in Stierlin collection (DEI) labelled: Heerii, (unreadable) [handwritten] / Italien [handwritten] / Historisches Exemplar [red, printed] / O. Heerii Stl., Bonn. [handwritten] / Des. L. Magnano, 1995.

Remarks. This species is presently transferred from O. (Otismotilus) REITTER, 1912 to $O$. (Rusnepranus) REITTER, 1912 (comb. nov.).

Otiorhynchus (Stupamacus) erroneus (FAUST, 1886), stat. nov. Brachyrrhinus (Otiorrhynchus) erroneus FAUST, 1886:141

Female lectotype in SMTD labelled: [golden square label] / Kavschan, Wilkins [handwritten] / erroneus, Faust [handwritten] / Type [red, printed] / Des. L. Magnano, 1995.

Remarks. $O$. erroneus is a valid species (stat. nov.), readily distinguished from $O$. russicus STIERLIN, 1883, by the stronger punctures of rostrum and by intervals between coarse pronotal punctures finely punctured. REITTER (1912) demoted O. erroneus to a "var." of $O$. russicus. In the FAUST collection there are three specimens of $O$. erroneus all with the red label printed "Type". The first is actually a female of $O$. erroneus and is surely the specimen used for the description of this species, whereas the remaining two belong to $O$. lubriculus FAUST.

Otiorhynchus (Stupamacus) infensus FAUST, 1888, comb. nov. Otiorhynchus infensus FAUST, 1888:149

Types (2) in SMND. Male lectotype labelled: [golden square label] / Tauria, Dohrn [handwritten] / Type [red, printed] / Des. L. Magnano, 1995. Female paralectotype: [golden square label] / Tauria, Dohrn [handwritten] / Type [red, printed] / Des. L. Magnano, 1995. 
Remarks. O. infensus is here transferred from O. (Microphalantus) REITTER, 1912 to $O$. (Stupamacus) REITTER, 1912 (comb. nov.).

Otiorhynchus (Stupamacus) pilosulus PENECKE, 1928

Otiorhynchus pilosulus PENECKE, 1928:37

Types (6) in the Penecke collection (SMTD). Male lectotype labelled: Thessalien, Olymp [handwritten] / Otiorhynchus, pilosulus m., Penecke det. [handwritten] / Typus [red, printed] / Des. L. Magnano, 1995.

Three males and two females paralectotypes: Thessalien, Olymp [handwritten] / Otiorhynchus, pilosulus m., Penecke det. [handwritten] / Typus [red, printed] / Des. L. Magnano, 1995.

Remarks. The study of the types confirmed the synonymy of $O$. pilosulus with $O$. clavalis APFELBECK, 1922, already proposed by LONA (1937).

\section{Otiorhynchus (Tournieria) cornicinus STIERLIN, 1861}

Otiorhynchus cornicinus STIERLIN, 1861:323

Female lectotype in the Heyden collection (DEI) labelled: 232 / cornicinus, Heyd., Ins. Jon., Parreyss [handwritten] / cornicinus Strl., = corneolus, Wse [pencil handwritten] / Syntypus [red, printed] / Des. Magnano, 1995.

\section{Otiorhynchus (Tournieria) emgei STIERLIN, 1887}

Otiorhynchus emgei STIERLIN, 1887:392

Lectotype in DEI labelled: Graecia [handwritten] / Syntypus [red, printed] / Lona vid. / O. emgei Stl [handwritten] / Des. L. Magnano, 1995.

Otiorhynchus (Tournieria) lubriculus FAUST, 1890

Otiorhynchus (Tournieria) lubriculus FAUST, 1890:322

Types (2) in SMTD. Female lectotype labelled: [golden square label] / Parnass, Krüper [handwritten] / lubriculus, Faust [handwritten] / Type [red, printed] / Des. L. Magnano, 1995. Female paralectotype: [golden square label] / Graecia, unreadable [handwritten] / lubriculus, Faust [handwritten] / Type [red, printed] / Des. L. Magnano, 1995.

\section{Otiorhynchus (Udonedus) koenigi FAUST, 1888}

Otiorhynchus koenigi FAUST, 1888:150

Types (5) in Faust collection (SMTD). Male lectotype (aedeagus dissected) labelled: [golden square label] / Cauc. occ., König [handwritten] / Type [red, printed] / Lectotypus, Korot. [yaev] design. 1990 / Des. L. Magnano, 1996. Male paralectotype: [golden square label] / Cauc. occ., Reitter [handwritten] / opertosus, Reitter [unpublished name by Reitter] / Type [red, printed] / Des. L. Magnano, 1996. Female paralectotype: Cauc. occ., König [handwritten] / coll. J. Faust [handwritten] / Syntypus, Otiorhynchus, koenigi Faust [red, handwritten] / paralectotype [red, handwritten] / Des. L. Magnano, 1996. Female paralectotype: [golden square label] / Cauc. occ., König [handwritten] / Typus [red, printed] / Des. L. Magnano, 1996. Male paralectotype: [golden square label] / Cauc. occ., König [handwritten] / Typus [red, printed] / Des. L. Magnano, 1996. 
Remarks. The funiculus of the left antenna of the lectotype was glued on the label; the tarsus of the front and middle right legs are lacking. The third above listed female paralectotype was re-mounted and the golden square label is lacking. The lectotype designation by KOROTYAEV has been not published, and is thus invalid.

Otiorhynchus (Urorrhynchus) truncatus STIERLIN, 1861

Otiorhynchus truncatus STIERLIN, 1861:53

Female lectotype labelled: [green square label] / female / Krain [handwritten] / Syntypus [red, printed] / O. truncatus, Schm. Schmidt [handwritten] / Des. L. Magnano, 1985.

Otiorhynchus (Zariedus) hystericus FAUST, 1892

Otiorhynchus hystericus FAUST, 1892:61

Male lectotype in SMND labelled: [golden square label] / Turkestan, Kultze [handwritten] / hystericus, Faust / Type [red, printed] / Des. L. Magnano, 1996.

Remarks. Right antenna and funiculus of left antenna are lacking in the lectotype.

\author{
Otiorhynchus (Zariedus) sedulus FAUST, 1894 \\ Otiorhynchus sedulus FAUST, 1894:54
}

Male lectotype in SMND labelled: [golden square label] / Kujuk, Hauser [handwritten] / sedulus, Faust [handwritten] / Type [red, printed] / Des. L. Magnano, 1996.

\title{
References
}

ARNOLDI, L. V. 1972: New species of the genus Otiorhynchus from the Caucasus. - Rev. Entomol. URSS, 51(1):127-132.

ARNoldi, L. V. 1975: Weevils of the genus Otiorhynchus GeRMAR (Coleoptera, Curculionidae) of Mongolia and of adjacent regions of the USSR. - Nasekomye Mongolii, 6(3): 254-284.

BehNe, L. 1991: Die Typen der von JohanN HeInRICH HochHUTH beschriebenen Curculionidae-Arten (Coleoptera) in der Sammlung des Deutschen Entomologischen Instituts. - Beitr. Entomol., 41(2): 401-404.

DANIEL, K. \& J. 1898: Otiorhynchus-Studien. 5 Bemerkungen zu bekannten Arten. Coleopteren-Studien. 2: 49-53.

FAUST, J. 1886: Verzeichniss der von den Herren Wilkins und GrumM-GrshimaïLo in Turkestan, Buchara und im Pamir gesammelten Curculioniden. - Horae Soc. Entomol. Ross., 20: 141-178.

FAUST, J. 1887: Verzeichnis der von Herrn L. CONRADT im östlichen Turkestan gesammelten Rüsselkäfer nebst Beschreibung neuer Arten. - Stett. Entomol. Zeit, 48: 291-304.

FAUST, J. 1888: Beiträge zur Kenntniss der Käfer des europäischen und asiatischen Russland mit Einschluss der Küsten des Kaspisches Meeres. - Horae Societatis Entomologicae Rossicae. 22: 147-180.

FAUST, J. 1890: Beiträge zur Kenntniss der Coleopteren-Fauna Südwest-Sibiriens. - Öfversigt finsk. Vet. Soc. Förhandl., XXXII: $1-54$.

FAUST, J. 1890: Rüsselkäfer aus den Mittelmeerländern. - Deut. Entomol. Zeitschr. (2): 321-336.

FAUST, J. 1892: Einige neue Curculioniden. - Deut. Entomol. Zeitschr., (1): 60-64.

FAUST, J. 1894: In HAUSER, F.: Beitrag zur Coleopteren-Fauna von Transcaspien und Turkestan. / Zusammengestellt unter Mitwirkung der Herren Dr. EPPELSHEIM, ESCHERICH, FAUST, Dr. VON HEYDEN, KuWERT, ReITTER und WeISE. - Deut. Ent. Zeitschr., 38(1): 32-66.

FAUST, J. 1899: Neue Curculioniden Madagaskars. - Abh. Ber. Zool. Anthrop. Ethnogr. Mus. Dresden, 2: 1-26.

FAUST, J. 1899: Zwei Curculioniden von der Insel Rhodos. - Wien. Entomol. Zeit., 18: 173-174. 
FORMANEK, R. 1907: Bestimmungs-Tabellen der europäischen Coleopteren. - LXI Heft (61). Curculionidae. 15 Teil Genus Trachyphloeus GeRM. - Wien. Entomol. Zeit., 26(4-5): 121-191

FORMANEK, R. 1926: Vier neue Rüssler der Gattung Otiorrhynchus. - Wien. Entomol. Zeit., 43: 142-146. GISTEL, J. 1857: Achthundert und zwanzig neue oder unbeschriebene Wirbellose Thiere charakterisirt von Doctor JOHANNES GiSTEL. - Straubing. Verlag der Schovner'schen Buchhandlung. Druck von J. F. KIETSCH in Landshut. pp. 94.

HEYDEN, L. 1886: Ueber Otiorhynchus tenuis STIERLIN aus Turkestan. - Deut. Entomol. Zeitschr., 30(1): 280. HoCHHUTH, I. H. 1847: Enumeration der Rüsselkäfer, welche von Baron MAXIMILIAN VON CHAUDOIR und von Baron A. v. GoTsCH auf ihren Reisen im Kaukasus und in Transkaukasia im Jahre 1815 gesammelt, wobei nebst Beschreibung der neuentdeckten Arten. - Bull. Soc. Nat. Moscou, 20(2): 448-587.

HосннUтH, I. H. 1851: Beiträge zur Kenntnis der Rüsselkäfer Russlands. - Bull. Soc. Nat. Mosc., 24(1): 3-102.

HoffmanN, A. 1950: Faune de France 52. Coléoptères Curculionides (Première partie). - Paris: Lechevalier. - $486 \mathrm{pp}$.

HoRN, W.; KAHLE, I.; FrIESE, G. \& GAEDIKE, R. 1990: Collectiones entomologicae. - Berlin: Akademie des Landwirtschaftswissenschaften. - 573 pp.

KIRSCH, T. 1880: Neue oder seltene Rüsselkäfer-Arten aus dem Gebiete des Mittelmeerbeckens. Entomol. Monatsbl. 2(1): 3-16.

LONA, C. 1936: Coleopterorum Catalogus auspiciis et auxilio W. JUNK editus a S. SCHENKLING. Pars 148. Curculionidae: Otiorrhynchinae. - Berlin: Junk. - 226 pp.

LoNA, C. 1937: Studi sugli Otiorrhynchus. II. - Boll. Soc. Entomol. Ital., 1937: 143-150.

MAGNANO, L.: Notes on the Otiorhynchus Germar, 1824 complex (Coleoptera: Curculionidae). In print.

PENECKE, K. A. 1928: Fünf neue Curculioniden der europäischen Fauna. - Col. Centralbl., 3(12): 37-45.

PENECKE, K. 1931: Zwei neue Otiorhynchus-Arten aus dem Karpathengebiete. - Col. Centralbl., 5(2-5): 117-123.

REITTER, E. 1912: Bestimmungs-Tabellen der europäischen Coleopteren. 66 Heft. Curculionidae, Subgenera der Gattung Otiorrhyncus. - Wien. Entomol. Zeit., 31(2): 45-67. (sep. 1-23).

ReITTER, E. 1912: Bestimmungs-Tabellen der europäischen Coleopteren. LXVII Heft (67). Curculionidae, Untergattungen Arammichnus GoZIS und Tyloderes SCHÖNHERR der Gattung Otiorrhynchus GeRMAR. Wien. Entomol. Zeit., 31(3-5): 109-154.

REITTER, E. 1913: Bestimmungs-Tabellen der europäischen Coleopteren. LXIX Heft (69).Curculionidae (20. Teil.). Die Ungezähnten Arten der Gattung Otiorhynchus. - Wien. Entomol. Zeit., 32(2-3): 25-118.

ReITTER, E. 1914: Bestimmungs-Tabellen der europäischen Coleopteren, 70 Die gezähnten Arten der Gattung Otiorrhynchus GeRM.: Dorymerus und Tournieria. - Verh. Nat. Ver. Brünn, 52[1913]: 1-123.

SCHÖNHERR, C. J.: In: FALDERMANN, F.: 1838 Fauna entomologica Trans-caucasica. Coleoptera. Pars III. - Ann. Soc. Imp. Nat. Moscou: 93.

SMRECZYNSKI, S. 1959: Otiorrhynchus noskiewiczi n. sp., sowie Übersicht der verwandten Arten (Artengruppe Eunihus ReITT., subgen. Otiorrhynchus s. str.). - Polsk. Pismo Entomol., 29(1): 1-15.

SOLARI, F. 1950: Curculionidi nuovi o poco conosciuti della fauna paleartica. XV. Sinonimie e nuove specie. - Mem. Soc. Entomol. Ital., 29: 28-51.

STIERLIN, G. 1858: Die Schweizerischen Otiorhynchen. - Berl. Entomol. Zeit., 2: 250-310.

STIERLIN, G. 1861: Revision der europäischen Otiorhynchus-Arten. - Berlin: Nicolai. - 135 pp.

STIERLIN, G. 1862: Erster Nachtrag zur Revision des europäischen Otiorhynchus-Arten. - Berl. Entomol. Zeit., 6: 358-378.

STIERLIN, G. 1872: Dritter Nachtrag zur Revision der europäischen Otiorhynchus-Arten. - Berl. Entomol. Zeit., 16: 321-368.

STIERLIN, G. 1875: Vierter Nachtrag zur Revision der europäischen Otiorhynchus-Arten. - Deut. Entomol. Zeit., 19(2): 417-434.

STIERLIN, G. 1876: Beschreibung einiger kaukasischer Rüsselkäfer. - Mitt. Schw. Entomol. Ges., 4[18721876] (9): 495-514.

STIERLIN, G. 1877: Neue caucasische Otiorhynchen gesammelt von HANs LEDER. - Deut. Entomol. Zeit., 211(1): $177-182 ; 182-188$. 
STIERLIN, G. 1879: Beschreibung einiger neuer Käferarten. - Mitt. Schw. Entomol. Ges., 5[18771879](9): 510-515.

STIERLIN, G. 1882: Beschreibung einiger neuer Rüsselkäfer. - Mitt. Schw. Entomol. Ges., 6[18801883](5): 250-256.

STIERLIN, G. 1883: Bestimmungstabellen der europäischen Coleopteren. IX Curculionidae. - Mitt. Schw. Entomol. Ges., 6[1880-1883](8-9): 403-645.

STIERLIN, G. 1885: Otiorhynchus tenuis STRL. n. sp. - Deut. Entomol. Zeit., 29(2): 294-295.

STIERLIN, G. 1886: In: HeYden, L. v. und KraATZ, G.: Beiträge zur Coleopteren-Fauna von Turkestan. Otiorhynchus (Tournieria) alaianus STIERLIN n. sp. - Deut. Entomol. Zeit., 30: 191-192.

STIERLIN, G. 1886: Beschreibung einiger neuer Rüsselkäfer. - Mitt. Schw. Entomol. Ges., 7[18841887](7): 282-286.

STIERLIN, G. 1887: Beschreibung neuer Rüsselkäfer und Bemerkungen. - Mitt. Schw. Entomol. Ges., 7[1884-1887]10: 390-399.

STIERLIN, G. 1892: Beschreibung einiger neuer Rüsselkäfer. - Mitt. Schw. Entomol. Ges., 8 [18881893](9): 357-366.

STIERLIN, G. 1893: Beschreibung einiger neuer europäischer Rüsselkäfer. - Mitt. Schw. Entomol. Ges., 8[1888-1893] (10) (1893): 408-412.

STIERLIN, G. 1896: Description de deux Curculionides nouveau d'Europe. - Le Frelon, 5(3), 1895-96: 44.

STIERLIN, G. 1899: Beschreibung einiger neuer europäischer Rüsselkäfer. - Mitt. Schw. Entomol. Ges. 10[1898-1903](5): 197-205.

STIERLIN, G. 1905: Beschreibung einiger neuer europäischer Rüsselkäfer. - Mitt. Schw. Entom. Ges., 11[1903-1909]: 56-57.

STRAND, E. 1917: Übersicht der in GISTEL's "Achthundert und zwanzig neue oder unbeschriebene wirbellose Thiere" (1857) behandelten Insekten. - Arch. Naturgesch., 1916(5): 75-101.

WEISE, J. 1906: Curculionidae (pp. 593-707). - In: L. vON HEYDEN; E. ReITTER and J. WEISE. Catalogus coleopterorum Europae, Caucasi et Armeniae rossicae. Editio secunda. Paskau, EdMUND RerTTer, [4]: $1-774$.

ZUMPT, F. 1936: Zur Kenntnis der Otiorhynchus carceli Gruppe. - Acta inst. mus. zool. Univ. Atheniensis: $112-120$.

\section{Author's address: \\ LUIGI MAGNANO \\ Via Ponte Rofiolo 2 \\ I- 37121 Verona \\ Italy}

